\title{
Superpredation patterns in four large European raptors
}

\author{
Rui Lourenço - Sara Maria Santos • \\ Joã o Eduardo Rabaça · Vincenzo Penteriani
}

\begin{abstract}
Predatory interactions among top predators, like superpredation or intraguild predation (IGP), can influence community structure. Diurnal raptors occupy high trophic levels in terrestrial food webs, and thus can regulate the presence of mesopredators. We studied superpredation (the killing and eating of another predator) in four large European raptors. We gathered 121 dietary studies, totalling 161,456 prey for the Goshawk Accipiter gentilis L., Golden Eagle Aquila chrysaetos L., Bonelli's Eagle Aquila fasciata Vieillot, and Eagle Owl Bubo bubo L. Results showed that superpredation: (1) is a widespread
\end{abstract}

Electronic supplementary material The online version of this article (doi:10.1007/s10144-010-0199-4) contains supplementary material, which is available to authorized users.

\section{R. Lourenço (\&) V. Penteriani}

Department of Conservation Biology,

Estación Biológica de Doñana, CSIC, c/ Americo Vespucio s/n, 41092 Seville, Spain

e-mail: rux@iol.pt

\section{R. Lourenço J. E. Rabaça}

Laboratory of Ornithology (LabOr), Department of Biology,

University of Évora, Núcleo da Mitra, 7002-554 Évora, Portugal

\section{R. Lourenço J. E. Rabaça}

Mediterranean Landscapes and Ecosystems Research Group,

ICAAM, Institute of Mediterranean Agricultural

and Environmental Sciences, University of Évora,

Núcleo da Mitra, 7002-554 Évora, Portugal

\section{S. M. Santos}

Department of Animal Biology, Centre of Environmental

Biology, Faculty of Sciences, University of Lisbon,

Campo Grande, 1749-016 Lisbon, Portugal

\section{Penteriani}

Finnish Museum of Natural History, Zoological Museum, University of Helsinki, 00014 Helsinki, Finland interaction in large raptors, but it can vary according to the top predator species; (2) is not an important energetic resource for large raptors, but rather seems mostly related to diet diversification when the main prey decreases; (3) is spatially clustered reflecting habitat heterogeneity, but shows no temporal or large-scale spatial trends; and (4) it is associated with lower breeding success of the top predator species. These findings support the food stress hypothesis as the main driving force behind increases in superpredation and IGP in raptors, with the decrease in breeding performance as a side effect. Superpredation by large raptors deserves future research to understand its effects on mesopredators, because on one hand it might contribute to promote biodiversity, while on the other hand, it can sometimes represent an additional risk for small populations of endangered mesopredators.

Keywords Food stress Generalist diet Intraguild predation Mesopredators Omnivory Top predators

\section{Introduction}

Despite the very rare use of the expression "superpredation", the concept of superpredator, a predator that eats and kills another predator, has been frequently used in ecology. Superpredation can include acts of intraguild predation (IGP), when the top predator kills and eats another species that is a potential competitor (Polis et al. 1989), but it has a broader sense that includes predation on several other carnivorous species that are not direct competitors. Superpredation might also sometimes be associated with omnivory, defined by Pimm and Lawton (1978) in a food web theory context as the feeding by one species on 
resources at different trophic levels. Superpredation differs from interspecific killing among predators, because it assumes that the prey (mesopredator) is always consumed. The consumption of mesopredators as carrion also falls outside the concept of superpredation, because it lacks the killing act.

As apex predators in many terrestrial communities, large raptors often engage in superpredatory interactions with other carnivorous species (Herrera 1973; Insley and Dugan 1973; Mikkola 1976; Real and Mañosa 1990; Tella and Mañosa 1993; Bosch et al. 2007). Studies focusing on terrestrial vertebrates have shown that predatory interactions among top predators can play a crucial role in structuring vertebrate communities, through the suppression or release of either the mesopredator or the prey (Palomares et al. 1995; Crooks and Soulé 1999; Fedriani et al. 2000; Sergio et al. 2003; but see also Vance-Chalcraft et al. 2007). Superpredation seems to be a widespread phenomenon in raptor assemblages, though frequently overlooked (Sergio and Hiraldo 2008), and besides densitymediated effects (direct killing), a superpredator is also likely to produce behaviourally mediated effects (associated with predation risk) on other carnivorous species (Creel and Christianson 2008). Superpredation has also been considered as a helpful tool in conservation biology, because top predators can sometimes regulate the densities of common mesopredators (Valkama et al. 2005; Sergio and Hiraldo 2008).

There is a great amount of information available on the diet of large raptors in Europe, but it has seldom been used to examine predatory interactions among large carnivorous vertebrates. In studies of IGP, the emphasis has been mainly put on the consequences for the mesopredator (Sergio and Hiraldo 2008), and the superpredator has assumed a central role less often. Thus, there are no extensive analyses on both the importance and energetic contribution of mesopredators in the diet of superpredators, or the compensatory role of this kind of prey when the main prey groups decline (see Tella and Mañosa 1993; Serrano 2000). Also, despite known spatial-temporal variations in biodiversity and community stability (Pianka 1966; Järvinen 1979; Järvinen and Ulfstrand 1980), no one has ever looked for large-scale patterns in superpredation or IGP in vertebrate top predators. Moreover, although some studies have tried to link IGP and breeding performance in raptors (Martínez and Calvo 2001; Martínez and Zuberogoitia 2001), to our knowledge there are no studies objectively relating superpredation rates and superpredator's fitness.

So, for a better understanding of superpredation in vertebrate top predators, we present a review study of this interaction in four large raptors that are at the top of food webs in European ecosystems: (1) the Goshawk Accipiter gentilis L. is a large hawk (*500-2,100 g) with a widespread distribution across Europe, and mainly associated with forest habitats; (2) the Golden Eagle Aquila chrysaetos L. is a large eagle $(* 2,800-6,700 \mathrm{~g})$ occurring in most European countries, although scarce from France to Poland; (3) the Bonelli's Eagle Aquila fasciata Vieillot is a large Mediterranean raptor (*1,500-2,500 g) occurring from Portugal to Turkey; and (4) the Eagle Owl Bubo bubo L. is the largest European owl ( $* 1,500-4,200$ g), being present in most countries (Cramp et al. 1977-1994).

This study had five main objectives: (A) to describe the frequencies of superpredation and the biomass contribution of carnivorous species in the diet of large raptors; (B) to analyse possible spatial and temporal variations in superpredation across Europe; (C) to understand the relations between superpredation and frequency of other prey in whole Europe, and then particularly in south-western Europe; (D) to relate superpredation with the apex predator's breeding performance; and (E) to analyse the results under the light of some proposed hypotheses for mechanisms behind IGP and superpredation.

\section{Methods}

Literature search

We searched for all the available studies covering the diet of Goshawk, Golden Eagle, Bonelli's Eagle and Eagle Owl, consulting several databases (e.g., IngentaConnect; Google Scholar), archives (e.g., JSTOR; SORA; BioOne) and publisher websites (e.g., ScienceDirect; SpringerLink; Wiley InterScience) (see S1 in Electronic Supplementary Material, ESM). As search terms, we used both the scientific and common names in the languages of most of the European countries where the four raptors occur. In each article, we also examined the cited references to look for other dietary studies which we might have missed in previous searches. Only the articles reporting: (1) the number of individuals consumed for all prey groups, or (2) the percentage of main prey groups (Class or Order level), were included in the analysis. Additionally, we only considered those studies that had a minimum sample size of 60 prey. Works presenting diet information for more than one study area, or for different time periods in the same area, were in most cases considered as different diet samples. We used the data about breeding success (total young fledged divided by pairs that started breeding) and population fecundity (total young fledged divided by total pairs in the population) if the studies also included this information for the same population, or if the authors cited a related article where the breeding data could be obtained. 
Data analysis

In cases where authors only listed the number of individuals consumed, we calculated the numeric percentage of each prey group. Superpredation on large carnivorous vertebrates (hereafter designated as mesopredators) was considered as the sum of the percentages of the following prey groups: Orders Carnivora, Falconiformes, Strigiformes (taxonomy of birds according to The Clements Checklist of Birds of the World, 6th edn, 2008). The option of analysing prey data at the Order level was chosen to deal with results presented at different taxonomic level (Species, Family, Order or even Class), and also because several prey species do not occur widely in Europe, making it impossible to compare geographically distant studies. As just a few studies presented the percentage of prey in terms of biomass consumed, we calculated the percentage of biomass for all the studies reporting a complete and detailed prey list. We used prey weights according to Cramp et al. (1977-1994) and MacDonald and Barret (1993), and also the diet studies included here.

Since most diet samples are usually related to periods of a few years, we used the central year of the period for each study as an explanatory variable. Whenever the coordinates were not mentioned in the paper, we used the author's description to find the study area in Google Earth (http:// earth.google.com) and extracted the central coordinates. With the central geographic point for each diet sample, we then obtained the correspondent biome according to the classification of Olson et al. (2001); see WWF website for a shapefile of the world ecoregions and biomes, http://www. worldwildlife.org//science/ecoregions/). We determined diet diversity for each sample study using the Shannon Diversity Index with the percentages of prey at the Order level. To correct the spatial autocorrelation among diet samples (neighbouring effects) we calculated an autocovariate term according to Augustin et al. (1996) and Dormann et al. (2007). Specifically for our objective B, we were also interested in quantifying the importance of the autocovariate as an effect influencing superpredation. In the remaining models, the autocovariate was used only to correct the spatial autocorrelation.

We used linear mixed-effects models (LMM; Pinheiro and Bates 2000) in objectives B and C, using the percentage of mesopredators as response variable, and in objective $\mathrm{D}$ using breeding success and population fecundity as response variables. The avian predator was included in the models as a random effect to account for the correlation between different diet samples within the same predator (Pinheiro and Bates 2000). Prior to each LMM procedure, we examined the data to detect nonnormal distribution and outliers in explanatory variables (Zuur et al. 2007). We applied a squared root transformation to the variables Rodentia, and Lagomorpha, a logarithmic transformation to the variables Galliformes, Columbiformes, and Passeriformes, and a binary transformation to the variables Insectivora, Artiodactyla and Reptilia. In the analyses of breeding success and population fecundity, the explanatory variable mesopredators was square root transformed. To avoid multicollinearity among explanatory variables within each model, we performed pairwise Pearson correlations amongst all explanatory variables and, if $|r| \boldsymbol{\Gamma} 0.7$, we excluded the one with lower correlation to the response variable, accounting for the biological meaning (Tabachnick and Fidell 2001). Models were fitted with restricted maximum likelihood (REML) that gives estimates of standard deviation generally less biased than the corresponding maximum likelihood (ML) estimates (Bolker et al. 2008). As heteroscedasticity, a common problem when analysing several studies (Gurevitch and Hedges 1999), was present in our datasets, we included a variance function to correct it (Pinheiro and Bates 2000). We used two variance function classes: power of variance covariate and exponential of variance covariate given by the fitted values (Pinheiro and Bates 2000). The choice was based on the best model (lowest AIC) and the analysis of the residual plots against fitted values and predictors (Zuur et al. 2007).

In the analysis of spatial and temporal patterns in superpredation (objective $\mathrm{B}$ ), we tested the effects of central year, coordinate $\mathrm{X}$, coordinate $\mathrm{Y}$ and autocovariate on the percentage of mesopredators $(n=116$ diet samples). We initially considered nine fixed effects (see S2 in ESM), but due to collinearity, five explanatory variables had to be discarded. In the study of the relations between superpredation and the frequency of other prey in whole Europe (objective C), we tested the effects of 11 explanatory variables (prey groups and diet diversity) on the percentage of mesopredators $(n=108$ diet samples). The variable "birds" was excluded due to collinearity problems. In the model for south-western Europe only (objective C), we tested the effects of the percentage of rabbits, central year and autocovariate on the percentage of mesopredators ( $\mathrm{n}=45$ diet samples). To test the effect of the consumption of mesopredators on breeding performance of avian predators (objective $\mathrm{D})$, we used two LMM, one with breeding success ( $n=30$ diet samples), and the other with population fecundity as the response variable ( $\mathrm{n}=32$ diet samples). In both models, we only tested the effects of the percentage of mesopredators and the autocovariate. All statistical analyses were carried out using R 2.9.0 statistical software (R Development Core Team 2009) with the packages: nlme 3.1-90 (Pinheiro et al. 2008) and spdep 0.4-34 (Bivand 2009). 
Table 1 Average percentage and biomass contribution of mesopredators in the diet of the four raptors

\begin{tabular}{|c|c|c|c|c|}
\hline Superpredator & Carnivores & Raptors & Owls & Mesopredators \\
\hline \multicolumn{5}{|l|}{ Goshawk (Accipiter gentilis) } \\
\hline Average percentage & $0.1 \pm 0.2(26)$ & $1.0 \pm 1.4(25)$ & $1.0 \pm 0.9(26)$ & $2.1 \pm 2.0(25)$ \\
\hline Average biomass (26,699 prey) & $0.2 \pm 0.6(24)$ & $1.7 \pm 3.8(24)$ & $0.8 \pm 0.9(24)$ & $2.7 \pm 4.3(24)$ \\
\hline \multicolumn{5}{|l|}{ Golden Eagle (Aquila chrysaetos) } \\
\hline Average percentage & $5.3 \pm 5.1(23)$ & $0.7 \pm 1.0(21)$ & $0.5 \pm 0.6(23)$ & $6.6 \pm 5.6(21)$ \\
\hline Average biomass (21,357 prey) & $7.5 \pm 8.3(20)$ & $0.3 \pm 0.4(20)$ & $0.3 \pm 0.8(20)$ & $8.0 \pm 8.5(20)$ \\
\hline \multicolumn{5}{|l|}{ Bonelli’s Eagle (Aquila fasciata) } \\
\hline Average percentage & $0.9 \pm 1.3(16)$ & $0.8 \pm 2.6(16)$ & $0.3 \pm 0.8(16)$ & $2.0 \pm 1.6(16)$ \\
\hline Average biomass (6,503 prey) & $1.1 \pm 2.1(16)$ & $0.4 \pm 0.5(16)$ & $0.2 \pm 0.4(16)$ & $1.8 \pm 2.0(16)$ \\
\hline \multicolumn{5}{|l|}{ Eagle Owl (Bubo bubo) } \\
\hline Average percentage & $0.8 \pm 1.2(50)$ & $1.2 \pm 1.6(47)$ & $2.4 \pm 2.7(47)$ & $4.4 \pm 3.9(50)$ \\
\hline Average biomass (61,782 prey) & $1.6 \pm 2.0(44)$ & $2.0 \pm 2.4(44)$ & $2.3 \pm 2.5(44)$ & $6.0 \pm 4.7(44)$ \\
\hline
\end{tabular}

Average percentages are presented with \pm SD and number of diet samples in parentheses

Results

Our diet review comprised 27 Goshawk (28 diet samples and 49,377 prey), 21 Golden Eagle (23 diet samples and 22,296 prey), 16 Bonelli's Eagle (16 diet samples and 6,503 prey), and 50 Eagle Owl studies (54 diet samples and 83,280 prey). Overall, we had 121 diet samples used to describe diet, but had to discard five samples where we could not determine the mesopredator percentage, hence the sample size used for analyses was 116. Considering that superpredation in raptors may be a rare event that could be underestimated for diet samples with few prey, we first checked our data for a possible effect of the sample size (total number of prey in each diet study) on the percentage of mesopredators. The LMM ( $\mathrm{n}=116$ diet samples) did not show any effect of the total number of prey on the percentage of mesopredators $(b=-0.18$, SE 0.18 , $\mathrm{df}=111, \mathrm{t}=-0.98, \mathrm{P}=0.33$ ), and thus we included all 116 diet samples in our review.

For an overview of the diet of the four predators in Europe, we present (S3 in ESM) the average percentage of the main prey groups (average percentage higher than 3.0\% for at least one predator). The Goshawk is mainly ornithophagous, but sometimes mammals can have an important contribution to its diet. Pigeons, doves, partridges, grouses, corvids and thrushes are the main prey. The Golden Eagle preys mainly on medium-sized mammals, although partridges and grouses also play an important role. Bonelli's Eagle's diet is mainly based on lagomorphs, partridges and pigeons. The Eagle Owl is the most dependent on mammals, with important contributions coming from rodents and lagomorphs. Average diet diversity at the Order level is very similar among the four species. The detailed list of the carnivorous prey for the four raptors in Europe is shown in S4 in ESM.

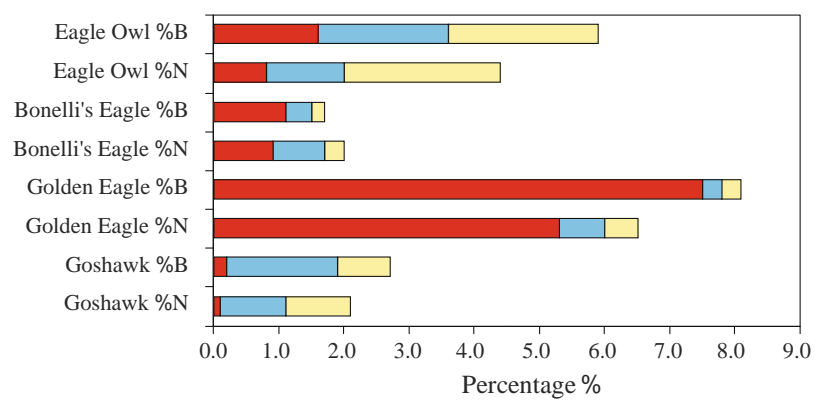

Fig. 1 Average numeric percentage $(\% \mathrm{~N})$, average biomass percentage $(\% \mathrm{~B})$, of mammalian carnivores (red/dark), diurnal raptors (blue/ grey), and owls (light yellow/light grey) in the diet of the Goshawk Accipiter gentilis, Golden Eagle Aquila chrysaetos, Bonelli's Eagle Aquila fasciata, and Eagle Owl Bubo bubo in Europe

Objective A: frequency and biomass of mesopredators in the diet of large raptors

The consumption of other predators was a widespread event in the diet of the four top predators, as only 7 out of 116 studies (6.0\%) had no mesopredators as diet items. The Golden Eagle showed the highest average percentage of mesopredators (6.6\%), mainly due to the contribution of mammalian carnivores (5.3\%). The Eagle Owl registered an average of $4.3 \%$ of mesopredators in the diet, capturing more owls $(2.4 \%)$ than the other three large raptors. Goshawk and Bonelli's Eagle consumed comparatively low percentages of mesopredators (2.1 and 2.0\%, respectively). The highest mesopredators percentage recorded in a diet sample was $8.1 \%$ for Goshawk, 20.2\% for Golden Eagle, $5.8 \%$ for Bonelli's Eagle and $20.7 \%$ for Eagle Owl. The average biomass percentage of mesopredators in the diet of Golden Eagle $(7.5 \% ; n=20)$ was the highest of the four raptors (Table 1; for clarity, results have also been plotted 

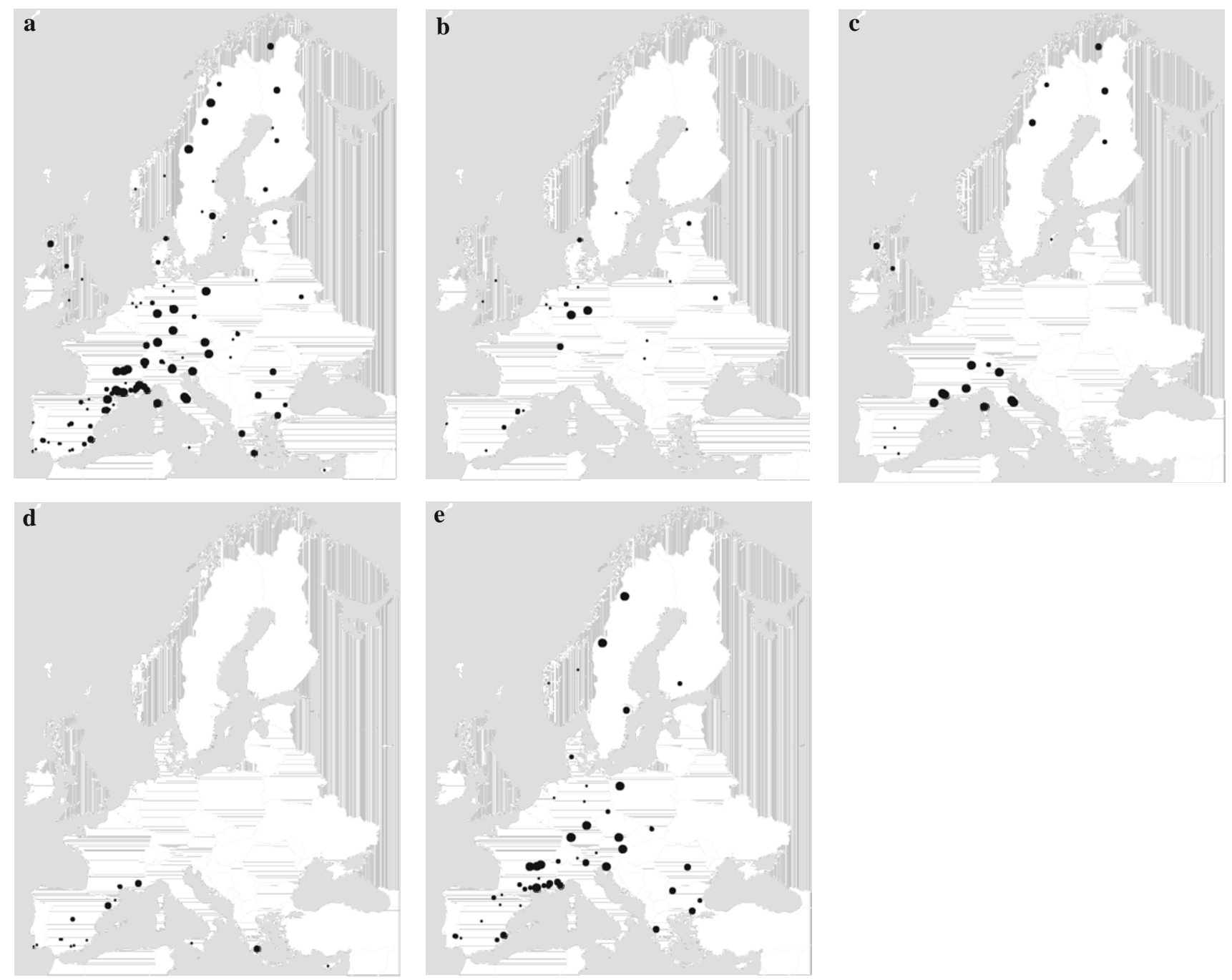

Fig. 2 Mapping of the diet samples with the percentage of mesopredators (circles correspond from smaller to larger to four classes of mesopredators percentage: $0.00-2.00,2.01-3.93,3.94-$ $6.00,6.01-21.00 \%)$. The value $3.93 \%$ was chosen for being the average mesopredators percentage for all the studies $(n=116)$. a All four raptors, b Goshawk Accipiter gentilis, c. Golden Eagle Aquila chrysaetos, d Bonelli's Eagle Aquila fasciata, e Eagle Owl Bubo bubo in Fig. 1). The Eagle Owl showed an average biomass percentage of mesopredators of $6.0 \%(n=44)$, while this value was $2.7 \%(\mathrm{n}=24)$ for Goshawk, and $1.8 \%(\mathrm{n}=16)$ for Bonelli's Eagle. The highest value of biomass percentage of mesopredators recorded in a diet sample was 33.1\% for Golden Eagle, 19.9\% for Goshawk, $17.7 \%$ for Eagle Owl, and 7.8\% for Bonelli’s Eagle.

Objective B: spatio-temporal patterns in superpredation

The LMM showed no evidence of temporal variation in the percentage of mesopredators $(b=-0.02, t=-0.92$, $\mathrm{P}=0.359$; see S5 in ESM). Also, we found no longitudinal $(\mathrm{b}=0.00, \mathrm{t}=0.11, \mathrm{P}=0.915)$ or latitudinal spatial trend $(\mathrm{b}=0.01, \mathrm{t}=0.23, \mathrm{P}=0.822)$ in the percentage of mesopredators. The autocovariate had a significant positive effect ( $b=0.75, t=4.07, P=0.000)$, indicating a spatial aggregation of similar values, with some areas concentrating high percentages of mesopredators (e.g., Central Europe), and others low percentages of mesopredators (e.g., Iberian Peninsula, Fig. 2).

Objective C: relation between superpredation and main prey frequencies in the diet

The LMM for Europe showed that the decrease in the percentage of rodents $(\mathrm{b}=-0.87, \mathrm{t}=-3.99, \mathrm{P}=0.000$; see S5 in ESM), rabbits and hares ( $b=-0.71, \mathrm{t}=-3.23$, $\mathrm{P}=0.002)$, partridges and grouse $(\mathrm{b}=-0.63, \mathrm{t}=-2.69$, $\mathrm{P}=0.009)$, and pigeons and doves $(\mathrm{b}=-0.80, \mathrm{t}=-3.14$, 
$\mathrm{P}=0.002$ ) had a significant effect in the increase of the percentage of mesopredators in the diet. On the other hand, the increase in the mesopredators percentage was related to a higher consumption of mammals $(b=0.08, t=3.00$, $\mathrm{P}=0.003)$ and to more diversified diets $(\mathrm{b}=12.79$, $\mathrm{t}=5.97, \mathrm{P}=0.000)$. The autocovariate had a positive significant effect $(b=0.32, t=2.65, P=0.009)$, indicating that the diet samples closer to each other had more similar mesopredators percentages. When we analysed only the samples from south-western Europe, there were no significant effects of the percentage of rabbits on the percentage of mesopredators in the diet $(b=0.01, t=0.52$, $\mathrm{P}=0.610$; see S5 in ESM). Also, there seemed to be no temporal trends in superpredation, given that the central year had no significant effect $(b=-0.02, t=-0.71$, $\mathrm{P}=0.48$ ). Once again, diet samples geographically close to each other had more similar percentages of mesopredators (autocovariate: $\mathrm{b}=0.77, \mathrm{t}=3.22, \mathrm{P}=0.003$ ).

Objective D: consumption of mesopredators and breeding performance

The decrease in breeding success of the four raptors was related to the increase in the percentage of mesopredators in the diet $(\mathrm{b}=-0.09, \mathrm{t}=-2.38, \mathrm{P}=0.026$; see $\mathrm{S} 5$ in ESM), while the mesopredators percentage showed no effect on the population fecundity of these top predators $(\mathrm{b}=-0.08, \mathrm{t}=-1.70, \mathrm{P}=0.10)$. Areas closer to each other had similar breeding success (autocovariate: $\mathrm{b}=$ $-0.13, t=-2.12, \mathrm{P}=0.044$ ), but the same effect was not found for population fecundity $(b=-0.01, t=-0.06$, $\mathrm{P}=0.954)$.

\section{Discussion}

General features and trends in superpredation by large raptors

This study shows that the capture of raptors and carnivores by large birds of prey and owls is a widespread phenomenon in most European study areas, although superpredation frequencies are highly variable between species and regions. From the studied predators, the Golden Eagle is the one consuming more mesopredators. Taking into account the amount of studies gathered, the obtained average percentages of mesopredators in the diet can represent good reference values of the level of superpredation by European large raptors to use in future studies. From these data, we can conclude that almost wherever large raptors occur, there can be a certain degree of effect on the populations of mesopredators. However, current knowledge does not allow the prediction of the effect of superpredation frequencies obtained from diet samples on mesopredator populations. This gap in our knowledge is a challenge for future studies and a research avenue that will surely lead to new monitoring tools in population and community ecology.

Superpredation frequencies can be influenced by many factors, such as the abundance and availability of the mesopredator. For example, the comparatively high percentage of mammalian carnivores in the diet of Golden Eagle were mainly associated with the predation on Red Fox Vulpes vulpes L. (e.g., Pedrini and Sergio 2001; Seguin et al. 2001; see S4 in ESM), which is a generalist and very common predator in Europe. When analysing the frequencies of superpredation (see S3 in ESM), it is possible to conclude that the most common mesopredators species in natural ecosystems are the ones that showed higher predation levels. Domestic populations of cats and dogs can sometimes represent profitable prey items, once they are common and less limited by food resources (generally provided by humans). Although these cases may inflate the role of superpredation on "natural" mesopredators, it is still worthwhile analysing them because this particular superpredation may assume an important conservation role, contributing to population control of alien species (Salo et al. 2008; Crooks and Soulé 1999). The overlap in the activity rhythms of predator and prey seems also relevant in determining levels of superpredation in different species, as for example, the Eagle Owl showed a higher average percentage of owls in the diet than the other three diurnal raptors. Still, there might be other factors causing distinct superpredation rates, but for which we cannot draw any conclusions, such as species-specific defence strategies (Palomares et al. 1996; Sergio et al. 2003, 2007; Zuberogoitia et al. 2008a).

Superpredation rate showed considerable spatial clustering at a small-scale but no large-scale spatial trends. So it seems that the known latitudinal and longitudinal trends in biodiversity and trophic diversity (Pianka 1966; Järvinen 1979; Korpimäki and Marti 1995) had no reflection on patterns of superpredation in Europe. Like IGP, superpredation also seems to be locally influenced by the community structure (e.g., diversity, habitat structure, productivity; Mylius et al. 2001; Holt and Huxel 2007; Janssen et al. 2007; Amarasekare 2008). The marked ecosystem patchiness that dominates Europe (Antrop 2004), creating a landscape mosaic and consequent variation in the structure of communities, appears to be the main driving force behind the spatial aggregation pattern in superpredation. In this sense, more thorough studies on how landscape and biodiversity affect interactions among top predators would be welcome.

We found no temporal trends at a large continental scale, but it does not mean that long-term temporal trends 
at a local scale do not exist. The diet of raptors and the superpredation rate can both change along short-time periods (Fernández 1993; Toyne 1998; Nielsen and Drachmann 1999; Martínez and Zuberogoitia 2001), but there are not enough data at a local scale to determine accurately the existence of long-term temporal trends. Moreover, the observed spatial heterogeneity in superpredation could have masked existing local-scale temporal trends. The Iberian Peninsula and southern France are areas where large raptors have been well studied, and where prey decline has been proved to cause large-scale temporal shifts in the diet (Moleón et al. 2009), but still we found no long-term temporal trends for south-western Europe. Considering all this, to address temporal variation in superpredation, future research should focus on long-term diet data on a local scale.

\section{Trophic determinants of superpredation by large raptors}

What drives large raptors to superpredation? The optimal diet of a predator results from the positive balance of the energy gained by the capture of prey compared to the energy spent searching and capturing it (MacArthur and Pianka 1966). Considering only their biomass, birds of prey, owls and carnivores should be worthwhile prey for the top predators examined in this study. But mesopredators normally do not make a profitable prey, because of the increase in time and energy needed to capture a scarce food resource and the risk associated in handling it. Nevertheless, any mesopredator that is of a size worth eating might be worth preying upon, if found by chance, and this might be especially true for predators under food stress caused by the decline of their main prey species.

Although variable, mesopredators represented a small contribution to the biomass ingested by the studied top predators, seldom reaching the same importance of other prey groups. The fact that mesopredators did not substitute main prey, together with the negative relations found between mesopredators and main prey percentages, and mesopredators percentage and breeding success of top predators, led us to conclude that increased superpredation in large raptors should mainly be a response to food stress, which causes, in generalist species, the widening of the diet breadth. Nevertheless, this might not be true for specialist species, unable to increase the trophic spectrum (Ferrer and Negro 2004).

In south-western Europe, rabbits are a staple prey of several apex predators (Delibes-Mateos et al. 2008), but their continuous decline could be a potential trigger for IGP and superpredation (Tella and Mañosa 1993; Serrano 2000). Despite the fact that the decline of rabbits can cause large- and local-scale shifts in the diet of raptors, with the increase in trophic diversity (Fernández 1993; Moleón et al. 2009), we found no evidence of a trend in superpredation in this region. Our results can have several interpretations: first, we could have had a sample size limitation for this particular analysis; second, we used diet at a largescale, and perhaps superpredation trends could have been easier to detect by comparing diet at a territory-scale; third, these raptors could overcome the decrease of an important prey like rabbits turning to locally available alternative prey species (partridges, pigeons, hares, hedgehogsFernández 1993; Mañosa 1994; Moleón et al. 2008); and fourth, despite prey decline, diet may have remained similar, although causing the decrease in breeding success and territory occupancy (Martínez and Calvo 2001; Martínez and Zuberogoitia 2001). Consequently, the relation between the decline of rabbits and superpredation in southwestern Europe does not seem to be as straightforward as it could be expected, with local nuances probably playing a role in this complex trophic interaction.

Some ecological mechanisms have been pointed out as potential triggers for IGP, which may also be related to superpredation: (1) in an opportunistic way, when their availability is high, carnivorous species can be seen merely as nutritionally profitable prey (Polis et al. 1989); (2) the decrease in main prey abundance (food-stress hypothesis) can lead apex predators to expand their diet and include mesopredators (Steenhof and Kochert 1988; Serrano 2000; Rutz and Bijlsma 2006); and (3) IGP facilitates the deliberate elimination of competitors, with additional energetic benefit (competitor-removal hypothesis; Serrano 2000). Another factor that might be in the origin of superpredation by raptors is the inherent risk that the top predator has to face when living near another predator that is also "built for the kill" (symmetrical IGP on adults and young, or mobbing; Mikkola 1976; Real and Mañosa 1990; Palomares and Caro 1999; Sunde et al. 2003; Zuberogoitia et al. 2008b), which could lead to a "kill before being killed" behaviour triggering IGP (that we designated as "predatorremoval hypothesis”; R. Lourenço et al., in preparation). In this way, a potential predator or mobber might be a preferential target of IGP by large raptors.

Our findings support the food-stress hypothesis, where increased superpredation is associated with decrease in the percentages of typical prey groups. So overall, this could be the main mechanism behind superpredation and IGP in large European raptors. The negative relationship found between the consumption of mesopredators and top predator's breeding performance also points to superpredation occurring mostly under food-stress situations, which are associated with a decrease in individual or population fitness. The absence of abundance data for the main prey and mesopredators in the study areas was a strong limitation to this study, because it could help to better understand the mechanisms behind superpredation. But food stress might 
not be the only determinant, and it would be important to determine the role of all factors. Moreover, because these determinants probably interact, it is difficult to explain and predict superpredation and IGP levels. To disentangle the role of these different causes behind superpredation it is necessary to design a holistic approach, which includes predator, mesopredators and prey abundance, but also experimental studies on the superpredator's behavioural mechanisms driving the competitor-removal and predatorremoval hypotheses.

The potential superpredation-related effect on large raptors

Considering that a high frequency of superpredation in top predators is not to be expected (Arim and Marquet 2004), and may result from a diversification of the diet to include mesopredators caused by food stress (Polis et al. 1989), there can be an associated loss of individual fitness, with effects at the population level of the top predator. Reduced breeding performance is a common individual response to stress situations in the life history of raptor species (Newton 1979), and decrease in food availability is a welldocumented cause (Fernández 1993; Steenhof et al. 1997; Martínez and Calvo 2001; Pedrini and Sergio 2002; Nyström et al. 2006).

Our results show that, despite a possible increase in superpredation as an effort to compensate situations of food stress, there are still some associated negative effects on breeding performance for the top predator. Therefore, the increase in superpredation can work as an alarm signal for decreasing breeding performance, probably associated with a decrease in prey availability. Thus, long-term studies on superpredation trends have the potential to represent a useful tool in conservation studies. This fact has another particular implication for apex predators, because it denotes that mesopredators do not seem to be profitable enough to ensure the fitness of individuals, being no good alternative to their usual main prey. Superpredation triggered by food stress does not seem to be part of the solution for the lack of main prey in large raptors, but on the contrary, it can be part of a problem for those mesopredator populations in less favourable situations. So, in those cases where evidence is gathered for food-stress superpredation, priority actions might be needed to recover the main prey populations of large raptors.

\section{Final remarks}

The concept of IGP has gathered a strong theoretical framework in the last decades (Polis et al. 1989; Holt and Polis 1997; Ives et al. 2005; Holt and Huxel 2007; Daugherty et al. 2007; Kimbrell et al. 2007; Amarasekare
2008). This theoretical basis can be useful to understand superpredation events and interspecific killing among predators. However, most observational and experimental studies have been carried out with invertebrates and freshwater vertebrates (e.g., Morin 1999; Amarasekare 2007; Borer et al. 2007; Vance-Chalcraft et al. 2007; Janssen et al. 2007). Only more recently has IGP and superpredation in raptors been focused on, though mostly based on observational studies, because experimental studies with this group face many ethical and logistic restrictions. Consequently, many theoretical expectations of IGP have never been checked in vertebrate predators. A premise for further studies is the existence of a large amount of information about interactions in vertebrate predators, namely predatory relations. Future analyses could benefit if there were more, well-distributed diet studies, so as to better deal with all the expected heterogeneity in a large area like Europe (Donázar et al. 1989). We found two main obstacles in the dietary literature of raptors: first, several studies did not present complete lists of prey numbers or frequencies, and second, sample sizes showed a large variation. Therefore, we strongly suggest that future diet studies should include complete prey lists (as on-line-only supplementary material), presenting future reviewers with larger sample sizes.

Mesopredators might also be consumed by raptors as carrion; thus, Golden Eagles regularly scavenge on dead animals (Marquiss et al. 1985; Pedrini and Sergio 2001; Seguin et al. 2001). As a consequence, some of the recorded mesopredators might have been consumed as carrion and not actually killed. In these cases, by studying diet only, we might have overestimated superpredation and consequently its potential effects on mesopredators. Therefore, in future studies and whenever possible, there should be a separation of predation and scavenging, because they have different implications for the mesopredator.

To better understand the causes behind predatory interactions among vertebrate apex predators, future studies should focus on long-term analyses with large sample sizes, relating superpredation to diet changes and abundance of mesopredators and main prey, and combined with experimental and observational studies testing some proposed hypotheses (competitor removal, predator removal, food-stress and opportunism). It would also be worthwhile putting some effort into the relationships between superpredation, diet diversity and breeding performance, mediated by the role of the availability of main prey. Finally, overlooked information can be obtained by studies assessing the effects of superpredation and IGP on both the mesopredator population dynamics and the community structure (e.g., diversity, complexity, spatial heterogeneity), as these interactions might be triggering unnoticed top-down effects. 
The study of IGP and superpredation in vertebrate predators is just now starting to unravel potentially strong interactions that are essential to understand the dynamics of vertebrate communities, and to ecological management. Landscape heterogeneity is an aspect to consider when studying these phenomena, being necessary to find the adequate scale. Furthermore, as vertebrates show behaviourally complex responses to predation risk (Palomares and Caro 1999; Sergio and Hiraldo 2008), it is particularly challenging to study these complex interactions. As a combination of competition and predation, IGP can contribute to high species diversity (Menge and Sutherland 1976), and trophic cascades and resource facilitation are two ways by which top predators can promote biodiversity (Sergio et al. 2008). But, when the mesopredator is a threatened species (e.g., Real and Mañosa 1990), then superpredation can mean an additional and demanding problem. Conservation biology urgently needs more clues about the positive and negative effects of superpredation and IGP in vertebrate top predators.

Acknowledgments We thank Michela Marchi-Bartolozzi for useful comments and English revision, and Maria del Mar Delgado who helped gathering references and ideas. Roger Jovani, José Antonio Sánchez Zapata and an anonymous referee made helpful suggestions that greatly improved the manuscript. During this work R.L. and S.M.S. were supported by doctoral degree grants from Fundação para a Ciência e a Tecnologia, Portugal (respectively, BD/27434/2006 and BD/21403/2005), and V.P. was granted by the Secretaría General de Universidades, Spanish Ministry of Education (Salvador de Madariaga Program).

\section{References}

Amarasekare P (2007) Trade-offs, temporal variation, and species coexistence in communities with intraguild predation. Ecology 88:2720-2728. doi:10.1890/06-1515.1

Amarasekare P (2008) Coexistence of intraguild predators and prey in resource-rich environments. Ecology 89:2786-2797. doi:10.1890/ 07-1508.1

Antrop M (2004) Landscape change and the urbanization process in Europe. Landsc Urban Plan 67:9-26. doi:10.1016/S01692046(03)00026-4

Arim M, Marquet PA (2004) Intraguild predation: a widespread interaction related to species biology. Ecol Lett 7:557-564. doi:10.1111/j.1461-0248.2004.00613.x

Augustin NH, Mugglestone MA, Buckland ST (1996) An autologistic model for the spatial distribution of wildlife. J Appl Ecol 33:339-347

Bivand R (2009) spdep: spatial dependence: weighting schemes, statistics and models. R package version 0.4-34

Bolker BM, Brooks ME, Clark CJ, Geange SW, Poulsen JR, Stevens MHH, White JSS (2008) Generalized linear mixed models: a practical guide for ecology and evolution. Trends Ecol Evol 24:127-135. doi:10.1016/j.tree.2008.10.008

Borer ET, Briggs CJ, Holt RD (2007) Predators, parasitoids, and pathogens: a cross-cutting examination of intraguild predation theory. Ecology 88:2681-2688. doi:10.1890/06-1707.1
Bosch R, Real J, Tintó A, Zozaya EL (2007) An adult male Bonelli’s eagle (Hieraaetus fasciatus) eaten by a subadult golden eagle (Aquila chrysaetos). J Raptor Res 41:338. doi:10.3356/08921016(2007)41[338:AAMBEH]2.0.CO;2

Cramp S, Simmons KEL, Perrins CM (eds) (1977-1994) The birds of the western palearctic, vol 1-9. Oxford University Press, Oxford

Creel S, Christianson D (2008) Relationships between direct predation and risk effects. Trends Ecol Evol 23:194-201. doi:10.1016/ j.tree.2007.12.004

Crooks KC, Soulé ME (1999) Mesopredator release and avifaunal extinctions in a fragmented system. Nature 400:563-566. doi: $10.1038 / 23028$

Daugherty MP, Harmon JP, Briggs CJ (2007) Trophic supplements to intraguild predation. Oikos 116:662-677. doi:10.1111/j.00301299.2007.15378.x

Delibes-Mateos M, Delibes M, Ferreras P, Villafuerte R (2008) Key role of European rabbits in the conservation of the Western Mediterranean Basin Hotspot. Conserv Biol 22:1106-1117. doi: 10.1111/j.1523-1739.2008.00993.x

Donázar JA, Hiraldo F, Delibes M, Estrella RR (1989) Comparative food habits of the eagle owl Bubo bubo and the great horned owl Bubo virginianus in six Palearctic and Nearctic biomes. Ornis Scand 20:298-306

Dormann C, McPherson J, Araújo M, Bivand R, Bolliger J, Carl G, Davies R, Hirzel A, Jetz W, Kissling W, Kühn I, Ohlemüller R, Peres-Neto P, Reineking B, Schröder B, Schurr F, Wilson R (2007) Methods to account for spatial autocorrelation in the analysis of species distributional data: a review. Ecography 30:609-628. doi:10.1111/j.2007.0906-7590.05171.x

Fedriani JM, Fuller TK, Sauvajot RM, York EC (2000) Competition and intraguild predation among three sympatric carnivores. Oecologia 125:258-270. doi:10.1007/s004420000448

Fernández C (1993) Effect of the viral haemorrhagic pneumonia of the wild rabbit on the diet and breeding success of the golden eagle. Rev Ecol Terre Vie 48:323-329

Ferrer M, Negro JJ (2004) The near extinction of two large European predators: super specialists pay a price. Conserv Biol 18:344349. doi:10.1111/j.1523-1739.2004.00096.x

Gurevitch J, Hedges LV (1999) Statistical issues in ecological metaanalyses. Ecology 80:1142-1149. doi:10.1890/0012-9658(1999) 080[1142:SIIEMA]2.0.CO;2

Herrera CM (1973) La captura de carnivoros por las strigiformes. Ardeola 19:439-444 (in Spanish with English abstract)

Holt RD, Huxel GR (2007) Alternative prey and the dynamics of intraguild predation: theoretical perspectives. Ecology 88:27062712. doi:10.1890/06-1525.1

Holt RD, Polis GA (1997) A theoretical framework for intraguild predation. Am Nat 149:745-764. doi:10.1086/286018

Insley H, Dugan D (1973) Buzzard and golden eagle feeding on other avian predators. Br Birds 66:310-311

Ives AR, Cardinale BJ, Snyder WE (2005) A synthesis of subdisciplines: predator-prey interactions, and biodiversity and ecosystem functioning. Ecol Lett 8:102-116. doi:10.1111/j.1461-0248. 2004.00698.x

Janssen A, Sabelis MW, Magalhães S, Montserrat M, van der Hammen T (2007) Habitat structure affects intraguild predation. Ecology 88:2713-2719. doi:10.1890/06-1408.1

Järvinen O (1979) Geographical gradients of stability in European land bird communities. Oecologia 38:51-69. doi:10.1007/ BF00347824

Järvinen O, Ulfstrand S (1980) Species turnover of a continental bird fauna: Northern Europe, 1850-1970. Oecologia 46:186-195. doi:10.1007/BF00540125

Kimbrell T, Holt RD, Lundberg P (2007) The influence of vigilance on intraguild predation. J Theor Biol 249:218-234. doi:10.1016/ j.jtbi.2007.07.031 
Korpimäki E, Marti CD (1995) Geographical trends in trophic characteristics of mammal-eating and bird-eating raptors in Europe and North America. Auk 112:1004-1023

MacArthur RH, Pianka ER (1966) On optimal use of a patchy environment. Am Nat 100:603-609. doi:10.1086/282454

MacDonald DW, Barret P (1993) Mammals of Britain and Europe. Harper-Collins, London

Mañosa S (1994) Goshawk diet in a Mediterranean area of Northeastern Spain. J Raptor Res 28:84-92

Marquiss M, Ratcliffe DA, Roxburgh R (1985) The numbers, breeding success and diet of golden eagles in Southern Scotland in relation to changes in land use. Biol Conserv 34:121-140. doi: 10.1016/0006-3207(85)90104-1

Martínez JE, Calvo JF (2001) Diet and breeding success of eagle owl in Southeastern Spain: effect of rabbit haemorrhagic disease. J Raptor Res 35:259-262

Martínez JA, Zuberogoitia I (2001) The response of the eagle owl (Bubo bubo) to an outbreak of the rabbit haemorrhagic disease. J Ornithol 142:204-211. doi:10.1007/BF01651788

Menge BA, Sutherland JP (1976) Species diversity gradients: synthesis of the roles of predation, competition, and temporal heterogeneity. Am Nat 110:351-369. doi:10.1086/283073

Mikkola H (1976) Owls killing and killed by other owls and raptors in Europe. Br Birds 69:144-154

Moleón M, Almaraz P, Sánchez-Zapata JA (2008) An emerging infectious disease triggering large-scale hyperpredation. Plos One 3:e2307. doi:10.1371/journal.pone.0002307

Moleón M, Sánchez-Zapata JA, Real J, García-Charton JA, GilSánchez JM, Palma L, Bautista J, Bayle P (2009) Large-scale spatio-temporal shifts in the diet of a predator mediated by an emerging infectious disease of its main prey. J Biogeogr 36:1502-1515. doi:10.1111/j.1365-2699.2009.02078.x

Morin P (1999) Productivity, intraguild predation, and population dynamics in experimental food webs. Ecology 80:752-760. doi:10.1890/0012-9658(1999)080[0752:PIPAPD]2.0.CO;2

Mylius SD, Klumpers K, de Roos AM, Persson L (2001) Impact of intraguild predations and stage structure on simple communities along a productivity gradient. Am Nat 158:259-276. doi: $10.1086 / 321321$

Newton I (1979) Population ecology of raptors. Poyser, London

Nielsen JT, Drachmann J (1999) Prey selection of Goshawks Accipiter gentilis during the breeding season in Vendsyssel, Denmark. Dansk Orn Foren Tidsskr 93:85-90

Nyström J, Ekenstedt J, Angerbjörn A, Thulin L, Hellström P, Dalén L (2006) Golden eagles on the Swedish mountain tundra-diet and breeding success in relation to prey fluctuations. Ornis Fenn 83:145-152

Olson DM, Dinerstein E, Wikramanayake ED, Burgess ND, Powell GVN, Underwood EC, D'Amico JA, Itoua I, Strand HE, Morrison JH, Loucks CJ, Allnutt TF, Ricketts TH, Kura Y, Lamoreux JF, Wettengel WW, Hedao P, Kassem KR (2001) Terrestrial ecoregions of the world: a new map of life on earth. Bioscience 51:933-938. doi:10.1641/0006-3568(2001)051 [0933:TEOTWA]2.0.CO;2

Palomares F, Caro TM (1999) Interspecific killing among mammalian carnivores. Am Nat 153:492-508. doi:10.1086/303189

Palomares F, Gaona P, Ferreras P, Delibes M (1995) Positive effects on game species of top predators by controlling smaller predator populations: an example with lynx, mongooses, and rabbits. Conserv Biol 9:295-305. doi:10.1046/j.1523-1739.1995.9020295.x

Palomares F, Ferreras P, Fedriani JM, Delibes M (1996) Spatial relationships between Iberian lynx and other carnivores in an area of south-western Spain. J Appl Ecol 33:5-13

Pedrini P, Sergio F (2001) Density, productivity, diet, and human persecution of golden eagles (Aquila chrysaetos) in the CentralEastern Italian Alps. J Raptor Res 35:40-48
Pedrini P, Sergio F (2002) Regional conservation priorities for a large predator: golden eagles (Aquila chrysaetos) in the Alpine range. Biol Conserv 103:163-172. doi:10.1016/S0006-3207(01)00116-1

Pianka ER (1966) Latitudinal gradients in species diversity: a review of concepts. Am Nat 100:33-46. doi:10.1086/282398

Pimm SL, Lawton JH (1978) On feeding on more than one trophic level. Nature 275:542-544. doi:10.1038/275542a0

Pinheiro JC, Bates DM (2000) Mixed-effects models in S and S-PLUS. Springer, New York

Pinheiro JC, Bates D, DebRoy S, Sarkar D, R Core Team (2008) nlme: linear and nonlinear mixed effects models. $\mathrm{R}$ package version 3.1-90

Polis GA, Myers CA, Holt RD (1989) The ecology and evolution of intraguild predation: potential competitors that eat each other. Annu Rev Ecol Syst 20:297-330. doi:10.1146/annurev.es.20. 110189.001501

R Development Core Team (2009) R: a language and environment for statistical computing. R Foundation for Statistical Computing, Vienna, Austria. ISBN 3-900051-07-0. http://www.R-project.org

Real J, Mañosa S (1990) Eagle Owl (Bubo bubo) predation on juvenile Bonelli's eagles (Hieraaetus fasciatus). J Raptor Res 24:69-71

Rutz C, Bijlsma RG (2006) Food-limitation in a generalist predator. Proc R SocLond B 273:2069-2076. doi:10.1098/rspb.2006.3507

Salo P, Nordström M, Thomson RL, Korpimäki E (2008) Risk induced by a native top predator reduces alien mink movements. J Anim Ecol 77:1092-1098. doi:10.1111/j.1365-2656.2008. 01430.x

Seguin JF, Thibault JC, Torre J, Bayle P, Vigne JD (2001) The diet of young golden eagles Aquila chrysaetos in Corsica: foraging in a man-made mammal fauna. Ardea 89:527-535

Sergio F, Hiraldo F (2008) Intraguild predation in raptor assemblages: a review. Ibis 150(S1):132-145. doi:10.1111/j.1474-919X. 2008.00786. $\mathrm{x}$

Sergio F, Marchesi L, Pedrini P (2003) Spatial refugia and the coexistence of a diurnal raptor with its intraguild owl predator. J Anim Ecol 72:232-245. doi:10.1046/j.1365-2656.2003.00693.x Sergio F,

Marchesi L, Pedrini P, Penteriani V (2007) Coexistence of a generalist owl with its intraguild predator: distance-sensitive or habitatmediated avoidance? Anim Behav 74:1607-1616. doi: 10.1016/j.anbehav.2006.10.022

Sergio F, Caro T, Brown D, Clucas B, Hunter J, Ketchum J, McHugh K, Hiraldo F (2008) Top predators as conservation tools: ecological rationale, assumptions, and efficacy. Annu Rev Ecol Evol Syst 39:1-19. doi:10.1146/annurev.ecolsys.39.110707. 173545

Serrano D (2000) Relationship between raptors and rabbits in the diet of eagle owls in southwestern Europe: competition removal or food stress? J Raptor Res 34:305-310

Steenhof K, Kochert MN (1988) Dietary responses of three raptor species to changing prey densities in a natural environment. J Anim Ecol 57:37-48

Steenhof K, Kochert MN, McDonald TL (1997) Interactive effects of prey and weather on golden eagle reproduction. J Anim Ecol 66:350-362

Sunde P, Bølstad MS, Desfor KB (2003) Diurnal exposure as a risk sensitive behaviour in tawny owls Strix aluco? J Avian Biol 34:409-418. doi:10.1111/j.0908-8857.2003.03105.x

Tabachnick BG, Fidell LS (2001) Using multivariate statistics. Allyn and Bacon, Boston

Tella JL, Mañosa S (1993) Eagle Owl predation on Egyptian vulture and northern goshawk: possible effect of a decrease in European rabbit availability. J Raptor Res 27:111-112

Toyne EP (1998) Breeding season diet of the goshawk Accipiter gentilis in Wales. Ibis 140:569-579. doi:10.1111/j.1474-919X. 1998.tb04701.x 
Valkama J, Korpimäki E, Arroyo B, Beja P, Bretagnolle V, Bro E, Kenward R, Mañosa S, Redpath SM, Thirgood S, Viñuela J (2005) Birds of prey as limiting factors of gamebird populations in Europe: a review. Biol Rev 80:171-203. doi:10.1017/ S146479310400658X

Vance-Chalcraft HD, Rosenheim JA, Vonesh JR, Osenberg CW, Sih A (2007) The influence of intraguild predation on prey suppression and prey release: a meta-analysis. Ecology 88:2689-2696. doi:10.1890/06-1869.1

Zuberogoitia I, Martínez JE, Zabala J, Martínez JA, Azkona A, Castillo I, Hidalgo S (2008a) Social interactions between two owl species sometimes associated with intraguild predation. Ardea 96:109-113

Zuberogoitia I, Martínez JE, Martínez JA, Zabala J, Calvo JF, Azkona A, Pagán I (2008b) The Dho-gaza and mist-net with Eurasian eagle-owl (Bubo bubo) lure: effectiveness in capturing thirteen species of European raptors. J Raptor Res 42:48-51. doi: 10.3356/JRR-05-31.1

Zuur AF, Ieno EN, Smith GM (2007) Analysing ecological data. Springer, New York 